\title{
Hydrology and the Imperial Vision of Bois de Boulogne
}

\section{By KEVIN COFFEE}

SUMMARY: Bois de Boulogne was a key urban design effort of Second Empire

France. This essay surveys the landscape of the park with particular attention to water; social practices that engendered the use of water, and social practices which water enabled. The hydrology of the site - the grand lake, streams, and waterfalls - is a statement and demonstration of imperial mastery and sensibility. Nearly half of the project budget was devoted to hydraulics and, in the opening years, more than 15\% of the municipal water supply was diverted to the park; all of which supported a statusladen array of features attractive to elites of the Second Empire and Third Republic.

keywords: landscape; water; urban parks; imperialism; Paris.

'We must have a stream here ... to give life to this arid promenade' - Louis Napoleon, $1848 .^{1}$

Landscapes, and particularly urban landscapes, are tracings of social practices compressed by time and in space. Ingold describes them as taskscapes collapsed into arrays of features. ${ }^{2}$ The present survey probes feature compression as a result of practices joined to class, gender and ethnic dispositions, through which many modern cities have emerged or redefined themselves. Modernity requires destruction in order to create its habitus $^{3}$ and 'eternal truths.' ${ }^{4}$ Consequently, as Bender notes, human-landscape relationships are always in-progress and the untidy products of conflict and unease. ${ }^{5}$

Archaeology assumes the task of untangling and deciphering untidy past practices of production, signification and use. This essay surveys the built encodings that re-made Bois de Boulogne as a public park and the loci of imperial prestige and social solidarity. Enmeshed with and actualizing these practices was the use of water. 


\section{A PALIMPSESTIC EXAMPLE}

A recent demonstration of the spatial compression of social practices was seen in the 20 October 2014, inauguration of Fondation Louis-Vuitton (FLV) by François Hollande, President of France. ${ }^{6}$ Built in the Jardin d'Acclimatation of Bois de Boulogne, this 'cathedral of light' is privately owned by Bernard Arnault, one of France's wealthiest citizens. Enveloped by massive steel sheets and visually floating in a reflecting pool, the FLV evokes a gigantic caravel, metaphorically referencing the trans-oceanic origins of le Jardin, and of the water which brings the park to life. ${ }^{7}$ The FLV was built despite objections from la Coordination pour la Sauvegarde du Bois de Boulogne, an advocacy group that describes FVL as a violation of the park as classified green space. Rather, the friends of M. Arnault in the Hôtel de Ville, the ministry of culture, and the Assemblée Nationale decreed his FLV to be a "public utility."

At the north end of le Bois de Boulogne, Jardin d'Acclimatation derives its name from le Jardin zoologique d'acclimatation du bois de Boulogne, the municipal zoo and botanic garden built at the height of the Second Empire. It's original mission also promised public utility: 'à multiplier et à répandre dans le public toutes les espèces animales ou végétales qui sont ou qui seraient nouvellement introduites en France, et paraîtraient dignes d'intérêt par leur utilité ou par leur agreement. ${ }^{9}$ Within the recreational scheme of the Bois de Boulogne, le Jardin zoologique d'acclimatation collected and bred plants and animals from every continent in a living display of empire. During the Third Republic, those displays included colonized persons from Africa and Asia, to illustrate 'the living connection between men and things.' ${ }^{10}$ The park conservatories, le Jardin fleuriste de la Muette in Passy, and the nursery at Longchamps incubated hundreds of non-native species and millions of plants with which to decorate the parks, avenues, boulevards and public squares of the city; visual emblems of colonial aspirations and influence. ${ }^{11}$ International students - from England, Germany, Belgium, Holland, and other imperial centers - studied horticulture in those gardens and greenhouses. ${ }^{12}$ With the eclipse of 19th century colonialism by late 20th century neo-liberalism, the greenhouses at Carrefour des Sablons, on the east edge of le Jardin d'acclimatation, were replaced by a 'kinesthetic discovery center' and the zoo-gardens superseded by boat and pony rides 
for children. ${ }^{13}$

\section{THE PARK ETAT ACTUEL}

The Bois de Boulogne comprises an irregular polyhedron of 846 hectares, ${ }^{14}$ and is among the largest landscaped urban parks of the modern capitalist era (Fig. 1). Fashioned from suburban woodland and royal hunting grounds, the project was authorized 8 July 1852 by Louis Napoleon as one of the first civic efforts of the Second Empire. ${ }^{15}$

Komara has well argued that the later landscape projects of the Second Empire exemplify sophisticated industrial and technological expertise. ${ }^{16}$ That expertise is clearly emergent in the Bois de Boulogne. Certainly, converting derelict woodlands into a modern urban park was no simple task, and required a complete re-envisioning that included earthmoving, re-vegetation and irrigation.

Such expertise did not arise by chance, it was marshaled by the state. Thus, in June 1853, after eleven months of trial-and-error, the floundering Bois de Boulogne project was assigned to Georges-Eugène Haussmann (1809-1891), a royalist career official who was made Prefect of the Seine in reward for his prominent support for the Emperor in Bordeaux (Haussmann's previous post). ${ }^{17}$ Haussmann quickly called upon Adolphe Alphand (1817-1891), his subordinate in Bordeaux, to lead les Service des Promenades and specifically attend to the Emperor's park project. ${ }^{18}$

Under Alphand's direction, the design of le Bois de Boulogne reflected an emerging ethic in which intersections of bourgeois morality, leisure and social cohesion were joined with nascent, coordinated (e.g. governmentally directed, privately financed) civic improvement. A similar mentality was demonstrating itself in Britain during this same period. ${ }^{19}$ Adjacent to the well-to-do arrondissements and faubourgs on the west side of the city, the Bois de Boulogne aggregated leisurely amusements which appealed to the boulevardier. Carriage roads, equestrian trails, walking paths, a racecourse, theatres, bandstands, conservatories and gardens, a zoo with aquarium, restaurants and cafes were built around an elaborate network of streams, lakes and cascades to enliven the sense and vitality of the park. An 1856 tour guide waxed ebulliently: 'at two o'clock, it begins to come alive; between four and five o'clock, it displays all its splendor.' ${ }^{20}$ 


\section{A PROMENADE WORTHY OF THE CAPITAL OF FRANCE}

In the summer following his coup d'état, Louis Napoleon obtained a F2,000,000 commitment from the municipal council to 'beautify' (l'embellissement) the Bois de Boulogne. ${ }^{21}$ The new régime envisioned this project as a demonstration of revived national aesthetics, engineering proficiency, capital capacity, and Imperial authority over space and time. ${ }^{22}$ It was also of avocational interest to Louis Napoleon, who periodically inspected the site and made specific recommendations regarding the work. ${ }^{23}$

Initially, 1200 men went to work under the direction of Louis Varé, landscape gardener to the Emperor's father, who Haussmann would describe in his Memoirs as 'practically illiterate.' Varé's attempt at building a serpentine lake produced a gully that could not hold water. Consequently, Haussmann sought out Alphand and appointed him to rescue the project. ${ }^{24}$ Alphand's solution for the lake was two basins at separate elevations supérieur and inférieur - joined by a small waterfall.

Alphand's collaborators included Jean-Pierre Barillet-Deschamps (1824-1873), jardinieren-chef du Service des Promenades et Plantations, Gabriel Davioud (1824-1881), architecte-en-chef du Service des Promenades et Plantations, and Eugene Belgrand (1810-1878), ingénieur en chef de 1re classe du Service des Eaux et Égouts, ${ }^{25}$ who also directed modernization of the municipal water and sewerage systems. Alphand, who envisioned the built environment as a monumental expression of prestige, concluded that the then-existing Bois de Boulogne 'no longer met the needs of our time and was not a promenade worthy of the capital of France. ${ }^{26}$

The resulting comprehensive plan for renovation proposed eight major developments:

1. The conversion of the old straight allées into winding roads, metalled for carriages, sanded for equestrians, or as shaded paths for pedestrians;

2. The excavation of water features and three brooks to feed the lakes, and that lead through those parts of le Bois made more picturesque by vegetation;

3. Creating the cascades at Mare aux Biches and Longchamps, at the most important points of the three streams; 
4. The creation of vast lawns around the lakes, in the area between Madrid and Bagatelle, and in the openings cut through toward la Muette, toward le Point du Jour, toward Boulogne, toward Saint-Cloud and le Mont-Valérien;

5. Plantings of large trees and shrubs: on the islands in the grand lake, surrounding the brooks and waterfalls, at all new entries into le Bois, and on either side of the main roads;

6. Reforesting the eliminated allées;

7. Construction of grottos and chalets on the lake islands;

8. Appropriation of new, wooded areas in the park at Madrid-Maurepas and the buildings on those lands. ${ }^{27}$

We began by digging two lakes and laying out the roads surrounding them. Dredged material from the excavations formed Butte Mortemart... The straight allées were eliminated and planted, and we created lawns bordering the water. ${ }^{28}$

\section{ALIMENTATION D’EAUX}

Park design demanded a tremendous volume of water to maintain the drives, irrigate hundreds of hectares of plantings, and fill the lakes and streams (Fig. 2). Initially, a $3.4 \mathrm{~km}$ pipeline brought water pumped from the Seine at Chaillot, near Pont de 1'Alma. ${ }^{29}$ That line ran southeast, beneath Avenue d'Eylau (now Avenue Victor Hugo), irrigating Jardin fleuriste de la Muette, entering the park at Porte de la Muette, and winding around the west edge of le Grand Lac to Butte Mortemart. A second line from Chaillot drove under Avenue de St. Denis (now Malakolf), entered the park at Porte Dauphine, and irrigated the western half of the park before returning across le Fond des Prince to Butte Mortemart. ${ }^{30}$

The Chaillot water pump proved both expensive and insufficient. Consequently, another pipeline was run from the reservoir further northwest at Monceaux and carrying water from Canal de l'Ourcq. That second main entered the park at Porte Maillot and ran along the abandoned carriage drive to the west side of lac Inférieur. A branch of that main followed Boulevard de Neuilly along the edge of the park to provision dwellings along the boulevard and special concessions such as Jardin d'Acclimatation. Continuing along Boulevard de Madrid, it ran past Porte de Bagatell and Porte de Seine, along the Champ 
d'Entrainment, through the Plain of Longchamps, and finally ended near Porte de SaintCloud.

In sum, an engineered network comprising $66,200 \mathrm{~m}$ of irrigating pipe was built, with 1985 hydrants and spigots installed every 30 to 40 meters along the principal routes of the park (Fig. 3). To this was added a system of rainwater cisterns located every 200 meters. The cost this entire delivery infrastructure was about $F 1,520,000(£ 60,800) .{ }^{31}$

The Chaillot and l'Ourcq mains were designed for redundant service. In the event of service interruptions, water could be directed from either source throughout the network. ${ }^{32}$ Water mains were an advanced design of bitumen-coated, welded wrought iron with a capacity of $18,000 \mathrm{~m}^{3} /$ day. Because of the supply cost and water pressure, Chaillot water serviced higher elevations of the park while l'Ourcq supplied the lakes, streams and cascades. ${ }^{33}$ Even this combined capacity proved insufficient and planning began for an artesian well just east of the park, in the faubourg of Passy (Fig. 4).

The well in Passy was intended for park-wide irrigation but specifically to supply water to large lakes. In December 1854, Haussmann approved funding and location, approximately one kilometer west of the grand lake. A design/build contract was signed with a Monsieur Kind, a hydraulic engineer from Saxony who had invented a new method for sinking wells of unprecedented depth and diameter. M. Kind quoted a maximum cost of F350,000 ( $£ 14,000$ ). Ultimately, the well cost more than F640,000. ${ }^{34}$ Drilling began in July 1855, but the work proved more problematic than anticipated. Because of the great depth and diameter $(71.1 \mathrm{~cm})$, the borehole and reinforcing tubes suffered several internal collapses, requiring unanticipated work and causing schedule delays. When the projected completion date arrived without success, work reverted to Alphand, Belgrand and the Services d'Ingénieurs, which rebuilt the borehole and made other repairs. Finally, in December 1861, after six and three-quarter years and at a bore depth of $586 \mathrm{~m}$, the well began sustained output of $6200 \mathrm{~m}^{3} /$ day at the required pressure, ${ }^{35}$ its outflow throttled back by nearly half in order to maintain pressure at the irrigation well in Grenelle some $3.5 \mathrm{~km}$ away which drew from the same aquifer. ${ }^{36}$ 
Despite all of the construction difficulties, the Passy project received international accolades from the engineering profession and particularly from the Royal Society of Arts in Britain. ${ }^{37}$ Models, drawings and photographs of the well and other built features of le Bois de Boulogne were also prominently featured at the 1862 International Exhibition in South Kensington, London. ${ }^{38}$

From 1856 onward, after the Plaine de Passy was annexed, many new streets were opened $^{39}$ enabling its transformation from horticultural land and isolated hôtels particuliére into a dense array of apartment blocks and townhouses. The wellhead was paved and planted to create Square Lamartine, between Avenue l'Empereur (Avenue Henri Martin) and Avenue d'Eylau (Avenue Victor Hugo) (Fig. 5, Fig. 6). The main entered the park at Porte de Muette and extended beneath Avenue de Saint Cloud and Chemin de Ceinture to the south end of lac Superieur.

The significance of water provisioning to the park is illustrated by comparison with requirements of Paris overall. The lakes and streams in Bois de Boulogne held approximately $198,500 \mathrm{~m}^{3}$. The total municipal water supply was $90,000 \mathrm{~m}^{3} /$ day in 1855 ; annexations and improvements increased that amount to about $180,000 \mathrm{~m}^{3}$ by 1865 . Between $26,000 \mathrm{~m}^{3}$ and $30,000 \mathrm{~m}^{3}$ was provided to Bois de Boulogne and another 15,000$16,000 \mathrm{~m}^{3}$ provisioned to Bois de Vincennes so that, in 1865 , approximately $25 \%$ of the municipal water supply was diverted to those two parks. ${ }^{40}$

\section{KEY FEATURES}

The Bois de Boulogne was transformed into a landscape replete with ponds, lakes and rivulets; features rare in London parks and which would inspire the design of New York's Central Park. ${ }^{41}$ The Parisian park was imagined as a center of leisure practices that would simultaneously demonstrate the superiority of French sensibilities and promote social solidarity among the propertied classes who were considered essential to the success of the Empire. As an 1867 city guide emphasized, 'going to the Bois is a tradition which one is careful not to miss ... an excellent occasion to display one's horses or mistress. ${ }^{42}$

\section{LES GRAND ET PETIT LACS}


Alphand's and Haussmann's interpretation of the central lake eclipsed in scope and size the Hyde Park example with which Louis Napoleon was familiar. In place of a single serpentine body of water, the finished lac compensated for the uneven terrain by employing a pair of basins joined across separate elevations. It provided the visual center for the massive processions of carriage riders and equestrians that converged daily on the Bois de Boulogne: "There are Parisian ladies who would certainly die every evening if they could not take a drive around the lake each day."43 And certainly the Emperor was often observed making a tour des lacs, "driving himself in his phaeton at a lively pace."44 Lac Supérieur covers $30,000 \mathrm{~m}^{2}$ and Lac Infériuer extends over $190,000 \mathrm{~m}^{2}$ with water cascading into the upper lake and continuing over a second waterfall into the lower lake (Fig.7). Excavation spoils were used in the re-vegetation of deprecated allées throughout the park and to build Butte Mortemart. Both lake basins are paved with mortar set stone and a $13 \mathrm{~cm}$ thick cement slab. Within the lower lake, eight hectares of artificial islands accessible only by boat (Fig. 8) - provide secluded walking paths and a chalet-styled restaurant built with imported Swiss materials. ${ }^{45}$ At the tip of the southerly island was built the Kiosque du Empereur, an elevated viewing platform and private gardening shed, ostensibly to support the Emperor's horticultural hobby. ${ }^{46}$

\section{RUISSEAU DE LONGCHAMPS}

Horseback riding at mid-century was an important display - especially by men - of personal and social vigor, and the park provided a network of sanded trails for that purpose. Bridle and pedestrian paths - the latter allowing equestrians to be admired follow along and cross back and forth over Ruisseau de Longchamps (Fig. 9). This forested promenade and stream simultaneously demonstrates several engineering solutions: the outlet for lac Inférieur; the conduit to Mare aux Biches; and the supply for the reservoir feeding the Grand Cascade. The 3.9-kilometer streambed was initially lined with clay, but was easily penetrable by water rats and thus required harder material. ${ }^{47}$

\section{GRAND CASCADE DE LONGCHAMPS}

The Grand Cascade was designed to be the spectacular zenith of the daily promenade. Carriages, equestrians and walkers gathered around the sculpted edifice in the afternoons, 
when it erupted as a waterfall $6 \mathrm{~m}$ high and $60 \mathrm{~m}$ wide (Fig. 10). The amount of water required for the daily display easily exceeded the rate available from the mains and so it was fed by a reservoir immediately north of the cascade, between Allée de Longchamps and Route de la Vierge aux Berceaux. This reservoir was created from a former quarry pit, approximately $8,000 \mathrm{~m}^{2}$ in area, which was also paved to retain water. The cascade edifice is built of quarried sandstone from Fountainebleau combined with elaborately sculpted cement, creating two interior galleries through which to walk and view the falling water from behind (Fig. 11). At $3000 \mathrm{~m}^{3}$ per hour, the water volume delimits the timing and duration of the waterfall and defines its attraction as an afternoon event.

\section{RUISSEAUX ET LA PLAINE DE LONGCHAMPS}

A network of streams flows from the collecting pool below the Grande Cascade and parallels the riding- and foot-paths that crisscross the Champ d'Entrainement. This ruisseaux was engineered to provide both visual interest to equestrians and flood protection for the Longchamps racetrack, itself a high-status amusement for members of the Jockey Club (Société d'encouragement pour l'amélioration des races de chevaux) and whose ranks included the extended Imperial family. Winding past Moulin de Longchamp, it feeds several smaller ponds including Étang de Longchamps, Étang de l'Abbaye, and Étang de Suresnes, before emptying into the Seine near Pont de Suresnes.

\section{MARE SAINT-JAMES AND LAC POUR LE PATINAGE (TIR AUX PIGEONS)}

These two small lakes were of out-sized importance to mid-century elites. Immediately adjacent to the formerly royal estates of Madrid and Saint James at the northwest side of the park, Mare Saint-James is a small, 1.2 hectare lake encircled by carriage drives and walking paths (Fig. 12). It was adapted from a gravel quarry and fed by Ruisseau de Saint-James which, along with Ruisseau de Armenonville, branches off from Ruisseau de Longchamps to flow through the northern third of the park. These streams were dug to resemble meanders but are fully engineered and paved canals that negotiate the uneven ground by means of multiple small weirs (Fig. 13).

Also just east of Porte de Madrid, the Lac Pour Le Patinage was initially built as the exclusive preserve of le Cercle des patineurs. The pond and surrounding edge were 
enclosed to seclude a private pavilion, in which club members socialized, dined, and fitted their skates. Their accompanying footmen sheltered in the partially enclosed porch at the front of the pavilion, which was heated with a small stove. The very shallow pond - approximately $0.3 \mathrm{~m}$ deep - facilitated thorough freezing but also afforded some safety

if the ice broke through. Other classes of park users were left to take their chances skating on the deeper lakes with sometime dreadful consequences. ${ }^{48}$ In 1866, Lac Pour Le Patinage was converted to a clay pigeon shooting range and still later, in 1899, the site was conceded to la Société pour l'Encouragement des Tirs en France, as reflected in the current name for the pond. ${ }^{49}$

In total, water comprises about 51.7 hectares or approximately $6.25 \%$ of the total ( $846 \mathrm{ha}$ ) area of Bois de Boulogne. The cost of landscaping the smaller lakes, streams and waterfalls amounted to F969,500, and earthwork for the two large lakes comprised F603,204, providing a base cost of F1,572,704. Additionally, the irrigation pipe network cost F1,520,000 and the well at Passy cost at least F640,000. Thus, within a construction budget of F7, $473,836^{50}$, more than F3.7 million - nearly 50\% - was committed to hydraulic components. ${ }^{51}$

\section{DISCUSSION}

I went out to the Bois the other day, when there were races going on ... the Avenue de l'Imperatrice, from the Arc de l'Etoile to the entrance of the Bois, was full of promenaders; and the main avenues of the Bois, from the chief entrance to the race-course, were lined with people, who stood or sat, simply to see the passing show. There could not have been less than ten miles of spectators, in double or triple rows, who had taken places that afternoon to watch the turnouts of fashion and rank. ${ }^{52}$

The public display of status metamorphosed through the eighteenth and nineteenth centuries, parallel to the metamorphosis of social classes. ${ }^{53}$ That transformation was actualized via a range of aesthetics and symbolic choices, including urban landscape and, specifically, park design. Thus, landscapes were re-created according to new elite 
sensibilities and distinguished the new social positions of landscape users; acknowledging and ranking class and status among promeneurs.

As highlighted by the several plebicites taken during the Second Empire, the French state attempted to closely orchestrate the body politic in support of the régime. ${ }^{54}$ That orchestration - as Haussmannization - was performed across the built environment as much as in the political and economic arenas. The Imperial building programs created highly lucrative opportunities for banking and industry while acknowledging populaire sentiments regarding work and recreation. The state simultaneously suppressed public discourse among the middle and working classes - through censorship of the press, criminalization of trade unions, and prohibitions against public gatherings - and promoted ostentatious public spaces for the haute bourgeoisie. It re-engineered the city to accentuate social segregation according to class and gender. ${ }^{55}$ In 1867 , after renovating the Bois de Boulogne as elitists' haven, a second great park was made on the east side of the city in Bois de Vincennes; accessible to les banlieues rouges and providing an improved drill ground for the army barracks stationed there. ${ }^{56}$

Thus, the Bois de Boulogne served both vieux and nouveau wealth. The network of carriage drives, equestrian trails and walking paths was used to enact upper class social status and cohesion. Those routes also delivered drivers to fine restaurants, specialized gardens and museums, a zoo of exotic animals, and the racetrack at Longchamps. Gardens, museums, zoo and racetrack, all operated under the auspices of closed cercles such as the la Société impériale zoologique d'acclimatation, la Société d'encouragement pour l'amélioration des races de chevaux, and la fondation du Cercle des patineurs. Membership determined access, whether to the skating pond at Porte de Madrid or to the luxurious tribunes at the Longchamp hippodrome. These embellissements lubricated the reciprocating effects of landscape, architecture, décorum, and solidarité; symbols of prestige and of the private/public financial partnerships that characterized imperial order.

One American observer described his 1867 experience of the Bois de Boulogne thus:

Of the number of vehicles present I can give you no estimate, save that they seemed to be miles in extent, while on both sides of the carriage-way rode 
horsemen and horsewomen, attired as only French people can dress. The fact that it was a Sunday afternoon undoubtedly added to the display. All conditions contributed - the haughty old noblesse, who boast of their unbroken descent from Charlemagne, or claim that the line of Louis le Grand (the XIVth) will be again restored, and who refuse to recognize either Orleans or Napoleon; the soldiers of the First Empire; the new-made nobleman who won his title in the battle of Solferino; the rich Americans who abound in Paris, some of them driving four-in-hand and spending the money of their fathers with a foolish profusion. ${ }^{57}$

The re-developed park knitted together the nephew's perceived mission of rebuilding the uncle's 'capital of capitals' 58 at the center of an expansive geo-political project. That project drew material impetus from a matrix of social relationships that extended throughout France and the contemporary world. ${ }^{59}$ Louis Napoleon's contingent position in place and time - the mystique surrounding his uncle, his refuge in Palmerstonian Britain, the collapse of the old régime in the otherwise rudderless 1848 revolution, his clique of co-conspirators in the coup d'état - produced a syncretic response in tension with those relationships. That tension eventually gave way to war and internal rebellion in $1870 .^{60}$

Louis Napoleon inherited a dense capital from his uncle's time, comprising a maze of narrow streets and tightly spaced buildings. Decades earlier, Mercier had estimated that two-thirds of those buildings were beyond repair and needed replacement. ${ }^{61}$ Seizing political opportunity from revolutionary chaos, Napoleon Bonaparte had declared his intention to re-make Paris 'not only [as] the most beautiful city in existence ... but also the most beautiful that could exist, ${ }^{, 62}$ and began improvement projects such as diverting the Ourcq into the city and rebuilding Rue de Rivoli. ${ }^{63}$ But such civic work was soon overtaken by the exigencies of expeditionary campaigns around the Mediterranean basin and wars with European monarchies, and ultimately halted when that Empire collapsed.

Transnational competition and contention, important drivers of that dynamic, were particularly acute between France and Britain. ${ }^{64}$ The collapse of the First Empire, the Congress of Vienna, and the Treaty of Paris reduced the geo-political and thus the socio- 
economic strength of France. Occupying armies, diplomats and adventurers helped themselves to Paris: artwork, books, precious metals, etc., became either fungible or booty. ${ }^{65}$ The economic subjugation of the Restoration régime engendered its inattention to public infrastructure and housing. Investments that did occur during the Restoration were privately organized, such as the canal and rail systems. Those approached but did not dramatically alter the capital. Underdevelopment also bred disease. The cholera epidemic of 1832-35 killed more than 18,400 Parisians; three times the number who died from that epidemic in London. ${ }^{66}$ An over-arching stress index was social unrest, such as ended the Bourbon Restoration in 1836 and produced the short-lived Second Republic in 1848. By 1855, one million Parisians were housed in 30,000 buildings. Fewer than 10,000 buildings received piped water and then only to the ground floor. ${ }^{67}$ Mid-century Paris was in pressing need of restructuring.

Louis Napoleon and his Prefect Haussmann forced themselves into the midst of this social and infrastructural dissonance - which the population was unwilling to abide and the old régime had proved incapable of mitigating - as conditions for building their new order. Inwardly, civic works projects injected billions of francs of capital activity into the French economy. Those projects created new strata of urban petit and haute bourgeoisie; employed thousands of workers from Paris and the countryside; and improved key infrastructural deficiencies such as communication, housing, water, sewerage, transport and green space. ${ }^{6}$ Outwardly, Hausmannisation enacted the Napoleonic directive to recreate Paris as the 'capital of capitals' or, as Haussmann characterized it, 'the imperial Rome of our day.' 69

The urban park-building efforts of the Second Empire were immense capital expenditures; gross costs for developing Bois de Boulogne alone surpassed F14,000,000. Even with creative accounting, land re-sales, and various concession contracts for park amenities, park building weighed on the prefectural budget, which underscores its importance to imperial strategy. Parks, and specifically the most elaborate examples, encompassed much more than genteel rus en urbe.

An explicit expression of how landscape architecture and transnational aspirations merged was given in Alphand's magnum opus, Les Promenades de la Ville de Paris; an 
expensively bound descriptive folio, fully illustrated with 131 full-sheet gravures and chromolithographs. The distribution list includes more than 800 special recipients, prioritized into three sets. The first set is headed by the sovereigns of Austria, Russia, Prussia, Italy, Belgium, Sweden, Bavaria, Denmark, Saxe, and Holland. The second set includes royalty of Spain, Wurtemberg, Romania, Lichtenstein, and HohenzollernSigmaringen, the Royal Library at Buckingham Palace and the British Museum library. The third set lists the Emperor of Brazil, mayors of Bonn, London, Manchester and Leeds, directors of the New York City public parks, South Kensington museum, Royal Institute of Architects, Royal Society of Horticulture in London, etc. ${ }^{70}$

Cosmopolitanism is manifested in standing structures; park exedra, gate-houses, pavilions, restaurants, and racecourse buildings. The Kiosque de l'Empereur reiterates an Ottoman motif; the restaurant on l'ile du lac Inférieur replicates a Swiss chalet. Botanic gardens, conservatories and plantations in the park display specimens collected from peripheral locales far from the French metropole. Mastery of the exotic is reiterated in the zoological garden.

Imperial technical mastery is heralded in the hydraulic engineering of the park. Major water lines were run through the city to service the park and a massive artesian well was built to reinforce that supply. Hundreds of water hydrants fed the artificial meadows and great beds of flowering plants. One hundred and twenty trackmen set out every morning to water the drives and suppress the dust that might corrode expensive carriages. Millions of litres daily fed the lakes, streams and waterfalls. Nearly half of the project budget was spent on water works and during the first decade of the Empire more than $15 \%$ of the municipal water supply was diverted just to Bois de Boulogne; in a city where most apartments lacked water service.

Louis Napoleon defined his leadership as 'taking the initiative in all that may promote the greatness and prosperity of France! ${ }^{71}$ Thus, Bois de Boulogne was re-created as a symbol of the Imperial government's capabilities, priorities and aspirations. The park project - within the massive re-development of Paris - showcased the depth and breadth of French technical expertise within the wider trans-Atlantic Industrial Revolution; it demonstrated the state's ability to marshal complex resources in a purposeful manner; 
Hydrology of Bois de Boulogne

and it also demonstrated the régime's material, political and ideological control, its ability to invent a new reality of urbanization. Governments and professional societies discussed and analyzed it; it became a model component of modern urbanization. Envisioned as a direct response to Hyde Park and Regent's Park in London, the New York City Central Park Commission took Bois de Boulogne as their template. ${ }^{72}$

Undergirding and illuminating that grand approach to urban renewal were the advanced civil engineering, architecture and especially hydro-engineering that re-animated the once 'arid promenade.'

Acknowledgements: My thanks to John Agnew for generously sharing his research regarding the 1861 International Exhibition at South Kensington. I am also indebted to the anonymous reviewers, whose insightful comments enabled me to improve this essay.

170 Kenwood Avenue, Oneida NY 13421, USA (kevin.coffee@museplan.com) 
Hydrology of Bois de Boulogne

\section{BIBLIOGRAPHY}

Abercrombie, P. 1912, 'Paris, Some Influences that have shaped its growth', Town Planning Review, 2:4, 309-320.

Agnew, J. 2015, 'The 1862 London International Exhibition: Machinery on Show and its Message', International Journal for the History of Engineering \& Technology, 85:1, 1-30.

Alphand, A. 1868, Les Promenades de Paris, Paris: Libraire De La Société Botanique De France.

Alphand, A., A. Deville, M. Hochereau (eds) 1886, Recueil des Lettres, Patentes, Ordonnances Décrets et Arrêtés Préfectoraux, Paris: Imprimerie Nouvelle.

Anon. 1855,'Paris Water Supply', Journal of the Society of Arts, 3:136, 556-557.

Anon. 1862a, 'French engineering and building in the International Exhibition, 1862', Civil Engineer and Architect's Journal, 25:July, 189.

Anon. 1862b, 'Foreign engineering models at the International Exhibition, 1862', Civil Engineer and Architect's Journal, 25:September, 292.

Anon. 1872, 'Boring machinery used in the construction of the Passy well', The Engineer, 34:August, 86-93.

Anon. 1892, 'Obituary. Jean Charles Adolphe Alphand, 1817-1891', Proceedings of the Institution of Civil Engineers, 107:1892, 390-392.

Anon. 1908, 'Terrible accident au Bois de Boulogne', Le Petit Journal, 26:Janvier, 1-2.

Anon. 2015. 'Le Jardin d'Acclimatation'. http://www.jardindacclimatation.fr/ accessed 4 September 2015.

Belgrand, E. 1866, Mémoire sur l'avant-Projet de Dérivation des Sources de la Vanne, Paris: Imprimerie Typographique et Lithographique de Jules-Juteau et Fils.

Bender, B. 2001, Contested Landscapes, Movement, Exile and Place, B. Bender \& M. Winer (eds), Oxford: Berg.

Bezucha, R. J. 1983, 'The French Revolution of 1848 and the Social History of Work', Theory and Society, 12:4, 469-484.

Bidou, H. 1937, Paris, Paris: Gallimard, 236. Cited in: Pinkney, D. H. 1955, 'Napoleon III's Transformation of Paris', Journal of Modern History, 27:2, 125-134.

Bourdieu, P. 2006, Outline of a Theory of Practice, Cambridge: Cambridge Univ Press.

Bravard, A. 2011, 'Le cercle aristocratique dans la France bourgeoise 1880-1939', Histoire, Économie et Société, 30:1, 85-99. 
Burnell, G. 1862, 'On some recently executed deep wells and borings', Civil Engineer and Architect's Journal, 25:March, 107.

Burnell, G. R. 1865, 'On the municipal organization of Paris, particularly with regard to the public works', Journal of the Society of Arts, 13:640, 240-249.

Cain, P. J. and A. G. Hopkins 1986, 'Gentlemanly Capitalism and British Expansion Overseas I. The Old Colonial System, 1688-1850', Economic History Review. 39:4, 501525.

Cain, P. J. and A. G. Hopkins 1980, 'The Political Economy of British Expansion Overseas, 1750-1914', Economic History Review, 33:4, 463-490.

Chadwick, G. F. 1966, The Park and the Town; Public Landscape in the 19th and 20th Centuries, New York: F. A. Praeger.

Chapman, B. 1953, 'Baron Haussmann and the Planning of Paris', Town Planning Review, 24:3,177-192.

Chapman, J. M. and B. Chapman 1957, The life and times of Baron Haussmann; Paris in the second empire, London: Weidenfeld and Nicolson.

Coffee, K. 2012, 'The Material Significance of Carriage Drives to the Design of Central Park', IA: The Journal of the Society for Industrial Archeology, 38:1, 75-92.

Cox, W. G. 1895, Artesian Wells, As a Means of Water Supply, Brisbane: Sapsford \& Co.

Crouzet, F. 1964, 'Wars, Blockade, and Economic Change in Europe, 1792-1815', Journal of Economic History, 24:4, 567-588.

Cullen, L. M. 1993, 'History, Economic Crises, and Revolution: Understanding Eighteenth-Century France', Economic History Review, 46:4, 635-657.

Delaporte, F. 1986, Disease and civilization: the cholera in Paris, 1832, Cambridge, MA: MIT Press.

Delvau, A. 1867, Les Plaisirs de Paris: guide pratique et illustré, Paris: A. Faure.

Edholn, F. 1993, 'The View from Below: Paris in the 1880s', in Bender B. (ed)

Landscape Politics and Perspectives, Providence/Oxford: Berg.

Evans, T. W. and E. A. Crane 1905, Memoirs of Dr. Thomas W. Evans: the second French empire, New York: D. Appleton and Company.

Forney, J. W. 1867, Letters from Europe, Philadelphia: Peterson \& Brothers.

Giovannini, J. 2014. 'An Architect's Big Parisian Moment', The New York Times, 20 October 2014, C1.

Goldberger, P. 2014. ‘Gehry’s Coup', Vanity Fair, September 2014. 
Harris, J. R. 1985, 'Industrial Espionage in the Eighteenth Century', Industrial Archaeology Review, 7:2, 127-138;

Harvey, D. 1990, The Condition of Postmodernity, Cambridge, MA: Blackwell.

Harvey, D. 2003. Paris, capital of modernity, New York: Routledge.

Haussmann, G.-E. 1890, Memoires du Baron Haussmann, v.1, Paris: Victor-Havard.

Haussmann, G.-E. 1893, Mémoires du Baron Haussmann, v. 3, Paris: Victor-Havard.

Hawley, J. B. 1935, ‘The Municipal Water Supply Of Paris', Journal, American Water Works Association, 27:8, 983-985.

Homans, H. W. 1870, 'France under the Second Empire', North American Review, 111:229, 402-444.

Hopkins, R. S. 2003. 'From place to espace: Napoleon III's transformation of the Bois de Boulogne', Proceedings of the Western Society for French History, 31, 197-211.

Houssaye, A. 1855, Les confessions IV, Paris; Dentu, 88, 93. Cited in: Pinkney, D. H. 1955, 'Napoleon III's Transformation of Paris: The Origins and Development of the Idea', Journal of Modern History, 27:2, 125-134.

I'Anson, E. 1859, 'On the recent improvements in Paris', Civil Engineer and Architect's Journal, 22:May, 157-160.

Ingold, T. 1993, 'The Temporality of the Landscape', World Archaeology, 25:2, 162.

Joanne, A. 1856, Les Environs de Paris Illustres, Paris: Librairie de L. Hachette.

Jordan, D. P. 1995, Transforming Paris: the life and labors of Baron Haussmann, New York: Free Press.

Kindleberger, C. P. 1961, 'Foreign Trade and Economic Growth: Lessons from Britain and France, 1850 to 1913', Economic History Review, 14:2, 289-305.

Kinney, L. W. 1987, 'Genre: A Social Contract?’, Art Journal, 46:4, 267-277.

Komara, A. 2003, 'Measure and map: Alphand's Contours of Construction at the Parc des Butte Chaumont, Paris 1867', Proceedings of the First International Congress of Construction History, Madrid. 1249-1255.

Komara, A. 2004. 'Concrete and the Engineered Picturesque the Parc des Buttes Chaumont (Paris, 1867)', Journal of Architectural Education, 58:1, 5-12.

Komara, A. 2009, 'Measure and Map: Alphand's Contours of Construction at the Parc des Buttes Chaumont, Paris 1867', Landscape Journal, 28:1, 22-39.

Kulstein, D. I. 1962, 'The Attitude of French Workers towards the Second Empire', French Historical Studies, 2:3, 356-375. 
Le Grix de la Salle, C. 2011, 'Fondation Louis Vuitton pour la création: Pas avant 2013', France-Amérique, 24 June 2011.

Mairie de Paris 2012, 'Bois de Boulogne : site du Tir aux Pigeons', Direction des Espaces Verts et de l'Environnement, Service du Paysage et de l'Aménagement.

Mansel, P. 2003, Paris Between Empires, Monarchy and Revolution 1814 - 1852, New York: St. Martin's Press.

Marx, K. 1963, The Eighteenth Brumaire of Louis Bonaparte, New York, International Publishers.

Merruau, C. 1875, Souvenirs de L'Hotel de Ville de Paris, 1848-1852, Paris: Pion. cited in: Pinkney, D. H. 1955, 'Napoleon III's Transformation of Paris: The Origins and Development of the Idea', Journal of Modern History, 27:2, 125-134.

Morris, R. J. 1976, Cholera, 1832: the social response to an epidemic, New York: Holmes \& Meier.

Olmsted, F. L. 1983 [1861], 'Frederick L. Olmsted to Board of Commissioners of the Central Park', letters dated 28 December 1859 and 22 January 1861, Papers of Frederick Law Olmsted, v. 3, C. E. Beveridge and D. Schuyler (eds), Baltimore: Johns Hopkins Univ Press.

Piketty, T. et al 2006, 'Wealth Concentration in a Developing Economy: Paris and France, 1807-1994', American Economic Review, 96:1, 236-256.

Pinkney, D. H. 1955, 'Napoleon III's Transformation of Paris: The Origins and Development of the Idea', The Journal of Modern History. 27:2, 125-134.

Pinkney, D. H. 1958, Napoleon III and the Rebuiding of Paris, Princeton: Princeton Univ Press.

Plessis, A. 1985, The rise and fall of the Second Empire, 1852-1871, Cambridge \& Paris: Cambridge Univ Press; Editions de la maison des Sciences de L'homme.

Potofsky, A. 2004, 'The Construction of Paris and the Crisis of the Ancien Régime: The Police and the People of the Parisian Building Sites, 1750-1789', French Historical Studies, 27:1, 9-48.

Price, R. 1984, 'Recent Work on the Economic History of Nineteenth-Century France', Economic History Review, 37:3, 417-434.

Rydell, R. W. 1984, All the World's A Fair, Chicago: University of Chicago Press.

Rydell, R. W. 1993, World of Fairs, Chicago: University of Chicago Press.

Shaya, G. 2004, 'The Flaneur, the Badaud, and the Making of a Mass Public in France, circa 1860-1910', The American Historical Review, 109:1, 41-77. 
Hydrology of Bois de Boulogne

Strang, J. 1859, 'On Water Supply to Great Towns: Its Extent, Cost, Uses, and Abuses', Journal of the Statistical Society of London, 22:2, 232-249.

Summerson, J. 1949, John Nash, Architect to King George IV, London: George Allen \& Unwin Ltd.

Tann, J. 2015. 'Borrowing Brilliance: Technology Transfer Across Sectors in the Early Industrial Revolution', International Journal for the History of Engineering \& Technology. 85:1, 94-114.

Tarlow, S. 2007, The archaeology of improvement in Britain, 1750 - 1850, Cambridge: Cambridge University Press.

Turcot, L. 2015, 'The rise of the promeneur: walking the city in eighteenth century Paris', Historical Research, 88:239, 67-99.

Vandam, A. D. 1895, 'Personal History of the Second Empire. IX. Intrigue and Corruption', The North American Review, 161:466, 352-361.

Warner, C. D. 1884, Saunterings, Boston: Houghton, Mifflin \& Co. 


\section{Hydrology of Bois de Boulogne}

\section{NOTES}

${ }^{1}$ Merruau 1875, cited in Pinkney 1955, 125-134.

${ }^{2}$ Ingold 1993, 162.

${ }^{3}$ Bourdieu 2006, 78-87.

${ }^{4}$ Harvey 1990, 16.

${ }^{5}$ Bender 2001, 2-3.

${ }^{6}$ Giovannini 2014, C1.

${ }^{7}$ Goldberger 2014. Frank Gehry refers only to the children's zoo in his site description although Goldberger reiterated a sea-faring reference by Gehry, comparing the building with the white whale in Moby Dick.

${ }^{8}$ Le Grix de la Salle 2011.

${ }^{9}$ Alphand 1868, 101.

${ }^{10}$ Rydell, 1984, 55-56; see also Rydell 1993, 68-72.

${ }^{11}$ Alphand 1868, 125-142.

${ }^{12}$ Alphand 1868, 129-130.

${ }^{13}$ Anon. 2015.

${ }^{14}$ Site boundary coordinates: 48.848794N, 2.227542E (SW); 48.847994N, 2.257744E (SE); 48.876152N, $2.246468 \mathrm{E}(\mathrm{NW}) ; 48.877549 \mathrm{~N} 2.28344 \mathrm{E}(\mathrm{NE})$.

${ }^{15}$ Alphand et al 1886, 265

${ }^{16}$ Komara 2003, 1249; Komara 2004, 5.

${ }^{17}$ Haussmann 1890, 504.

${ }^{18}$ Haussmann 1893, 121-132. Alphand studied at the École Polytechnic in Paris and the École des Ponts et Chaussées. All infrastructure service directors under Haussmann received the title 'engineer-in-chief';

Alphand's Service des Promenades orchestrated all architecture and horticulture in the parks. See also: Komara 2009, 22-39; Anon. 1892, 390-392.

19 Tarlow 2007; Summerson 1949.

${ }^{20}$ Joanne 1856, 14: 'A partir de deux heures, il commence à s'animer; entre quatre et cinq heures il est dans tout son eclat.'

${ }^{21}$ Alphand et al 1886, 265.

${ }^{22}$ Pinkney 1958, 52; Hopkins 2003.

${ }^{23}$ Evans and Crane 1905, 36; Chadwick 1966, 155.

${ }^{24}$ Haussmann 1890, 121-132; Chadwick 1966, 155-156; Chapman and Chapman 1957, 86-88; Burnell 1865, 240- 


\section{Hydrology of Bois de Boulogne}

249.

${ }^{25}$ Chadwick 1966, 152-156; Hawley 1935, 983-985. Hawley credits Belgrand with inventing the term 'hydrology.'

${ }^{26}$ Alphand 1868, 3. Translations by author.

${ }^{27}$ Alphand 1868, 4.

${ }^{28}$ Alphand 1868, 3.

${ }^{29}$ I'Anson 1859, 157-160.

${ }^{30}$ Alphand 1868, 15.

${ }^{31}$ Alphand 1868, 10-11, 15-26. Plate 2 of the appendix delineates this network in red ink.

${ }^{32}$ Alphand 1868, 16.

${ }^{33}$ Alphand 1868, 5.

${ }^{34}$ Burnell 1862, 107; and Cox 1895, 10; place the well cost at $\sim$ F1,000,000 (£40,000).

${ }^{35}$ Alphand 1868, 114-124; Anon. 1862b, 292.

${ }^{36}$ Alphand 1868, 123-124.

${ }^{37}$ Burnell 1862, 77-79; Anon. 1872, 86-93.

${ }^{38}$ Anon. 1862a, 189; Anon. 1862b, 292.

${ }^{39}$ Alphand et al 1886, 338-340.

40 Belgrand 1866, 3-5; Alphand 1868, 5; Anon. 1855, 556-557. In addition to the $8,000 \mathrm{~m}^{3}$ drawn from Passy, $18,000 \mathrm{~m}^{3}$ was drawn from l'Ourcq, and additional water pumped from Chaillot and diverted to Bois de Boulogne; at least $15,000 \mathrm{~m}^{3}$ was raised at Saint-Maur along l'Ourcq for Bois de Vincennes.

${ }^{41}$ Olmsted 1983, 234-236, 297-319.

${ }^{42}$ Delvau 1867, 35, cited in Hopkins 2003, 201.

${ }^{43}$ Cited in Pinkney 1958, 99.

${ }^{44}$ Hopkins 2003, 202.

${ }^{45}$ Alphand 1868, 87.

${ }^{46}$ Chadwick 1966, 155.

${ }^{47}$ Alphand 1868, 28.

48 e.g. Anon. 1908, 1-2; reports a skating accident involving 30 persons on lac Inférieur, resulting in at least two deaths.

${ }^{49}$ Mairie de Paris 2012, 5. 


\section{Hydrology of Bois de Boulogne}

${ }^{50}$ Alphand 1868,6. The construction budget excludes costs for acquiring land; the complete project budget was greater than F14,352,000. Using an equivalency of F2:USD1, the complete cost was considerably less than that of New York's Central Park, c.f. Coffee 2012, 76.

${ }^{51}$ Alphand 1868, 6, 8, 26, 36, 118, 120.

${ }^{52}$ Warner 1884, 11.

53 Turcot 2015, 67-99; Bravard 2011, 85-99; Shaya 2004, 41-77.

${ }^{54}$ Homans 1870, 402-444; Vandam 1895, 352-361; Marx 1963.

${ }^{55}$ Harvey 2003, 141-152; Kinney 1987, 267-270; Edholm 1993, 139-165.

${ }^{56}$ Alphand 1868, 157-158.

${ }^{57}$ Forney 1867, 184-185.

${ }^{58}$ Houssaye 1885, 88-93. Cited in: Pinkney 1955, 125-134.

59 e.g. Bezucha 1983, 469-484; Kindleberger 1961, 289-305; Kulstein 1962, 356-375; Homans 1870, 402444; Piketty et al 2006, 236-256; Price 1984, 417-434. Essential factors of the coup were internal sociopolitical stability amid transnational economic crises, and competition among European powers for markets and resources in Europe, the Americas and Africa.

${ }^{60}$ Homans 1870; Vandam 1895; Marx 1963

${ }^{61}$ Potofsky 2004, 9-48.

62 Bidou 1937, 236. Cited in: Pinkney 1955, 125-134.

${ }^{63}$ Abercrombie 1912, 309-320.

${ }^{64}$ Harris 1985, 127-138; Tann 2015, 94-114; Agnew 2015, 1-30. See also: Cain and Hopkins 1986, 501 525; Cain and Hopkins 1980, 463-490; Crouzet 1964, 567-588; Cullen 1993, 635-657.

${ }^{65}$ Mansel 2003, 93, 144, 155.

${ }^{66}$ Delaporte 1986; Morris 1976.

${ }^{67}$ Strang 1859, 232-249.

${ }^{68}$ Plessis 1985; Pinkney 1958; Chapman 1953,177-192. Chapman describes 'military problems' in 'the most dangerous parts of the city' resolved by creating straight and wide highways across Paris.

${ }^{69}$ Jordan 1995, 273.

${ }^{70}$ Alphand 1868, i-xii.

${ }^{71}$ Homans 1870, 418.

72 c.f Olmsted 1861 [1983], 234-235, 309. New York city government repeatedly cited the Bois de Boulogne as important model for their planned Central Park, and attempted to recruit Alphand to direct its construction. 


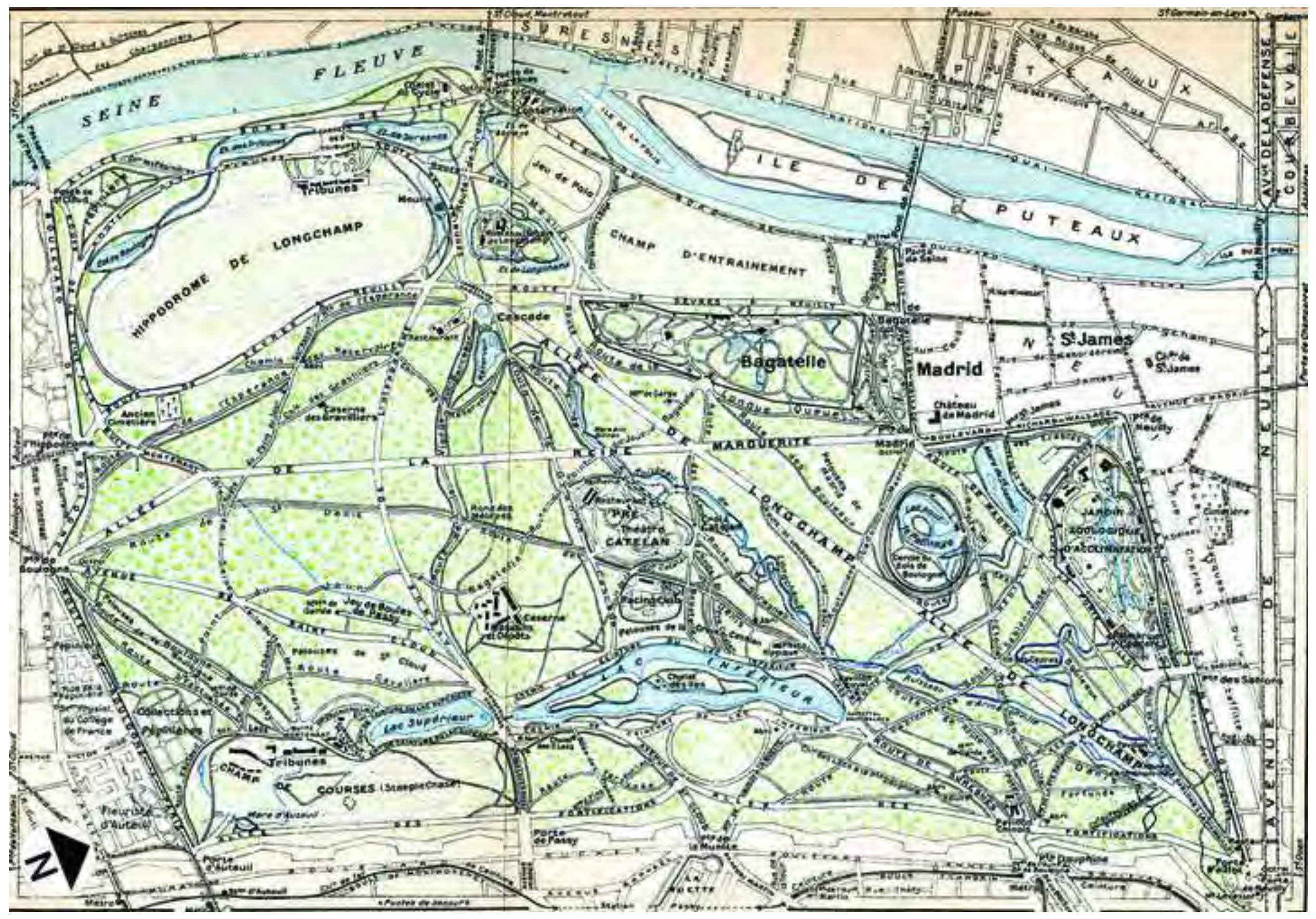




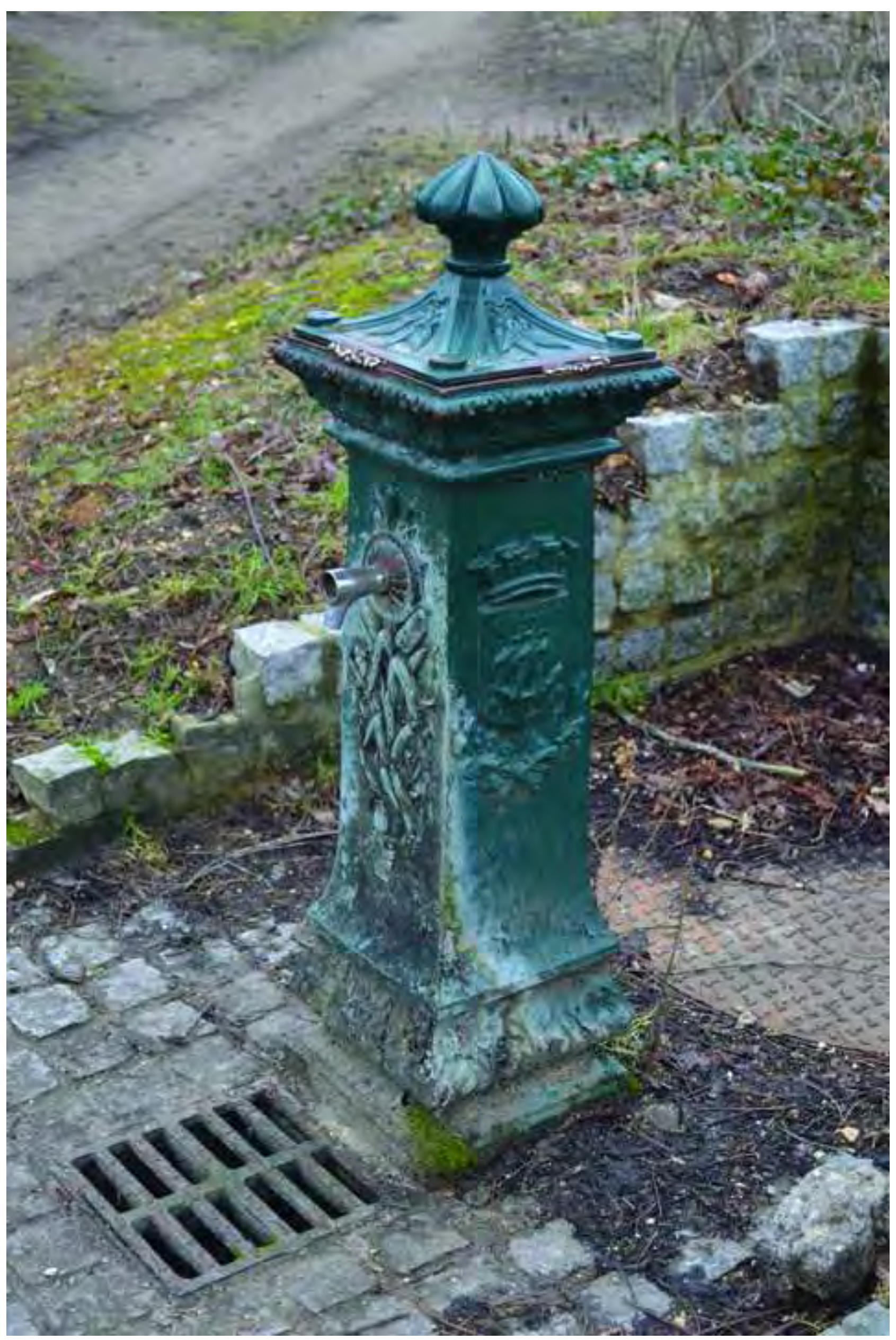




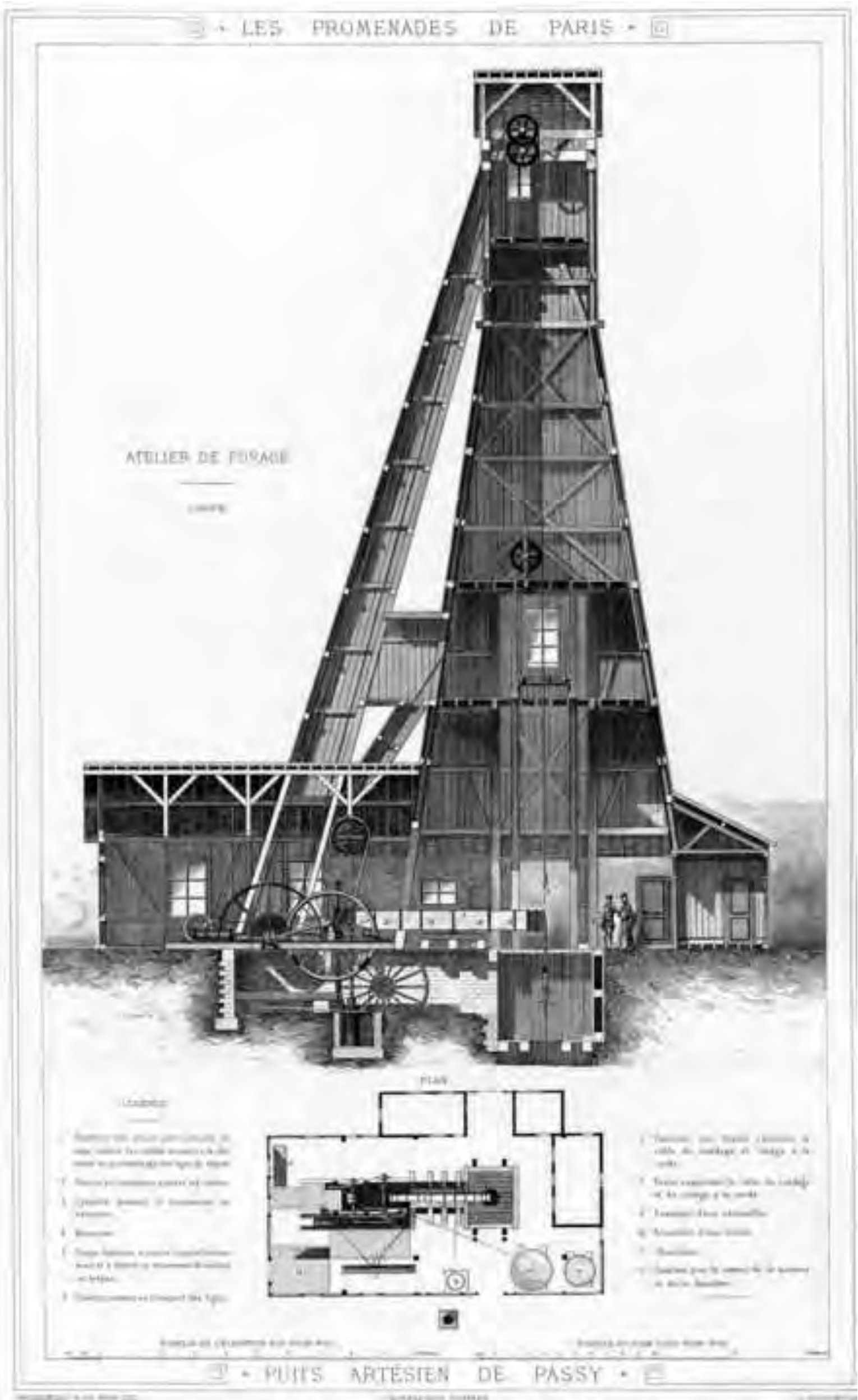




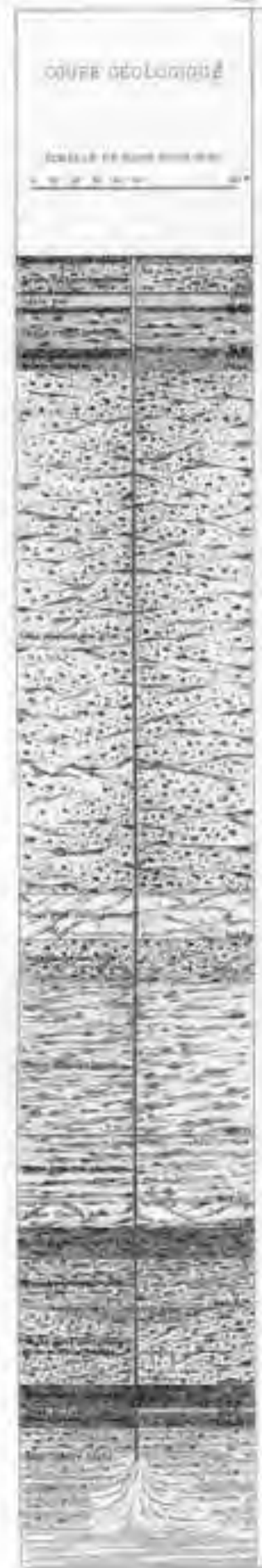

- LES PROMENADES DE PARIS .
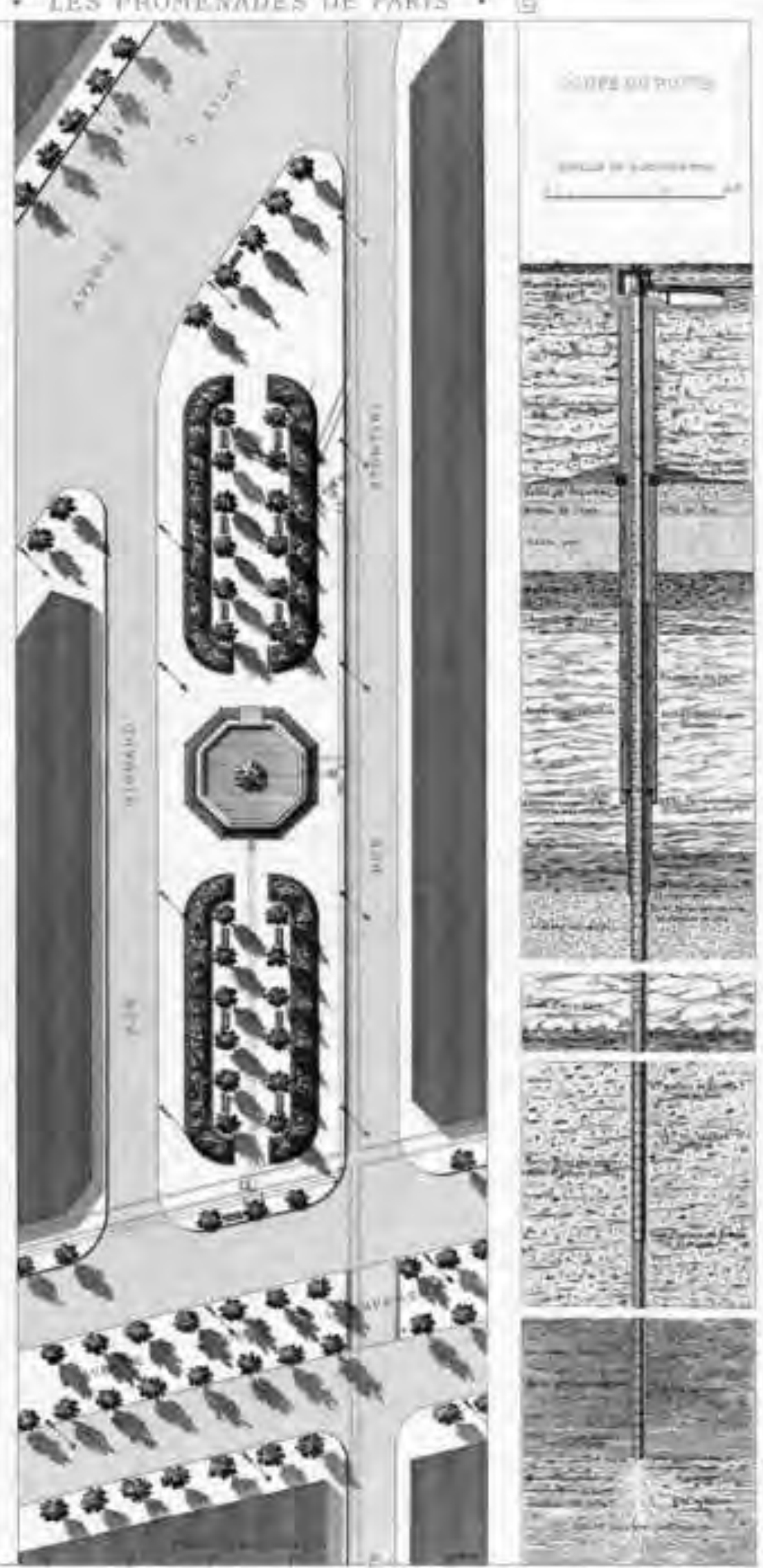


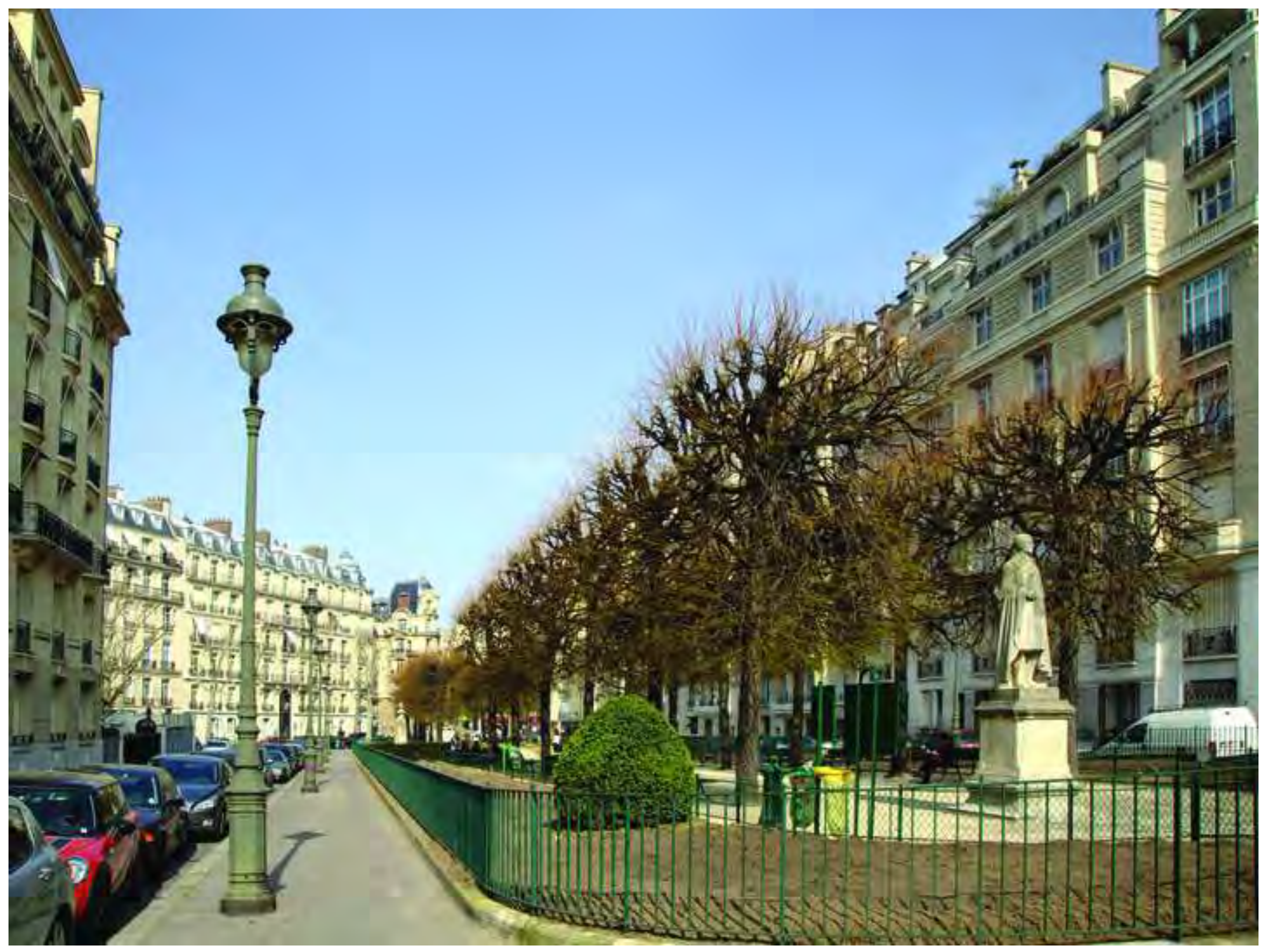




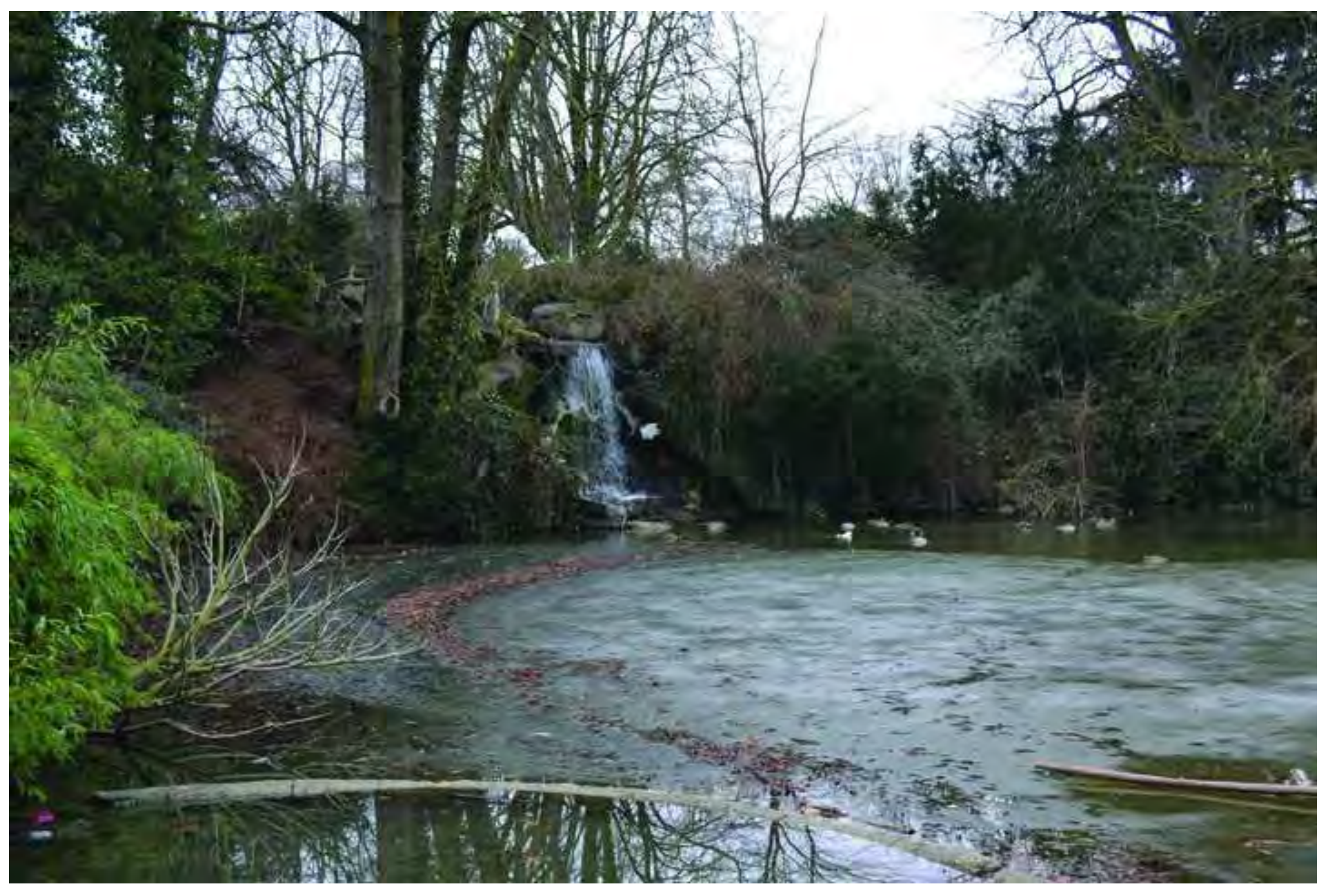




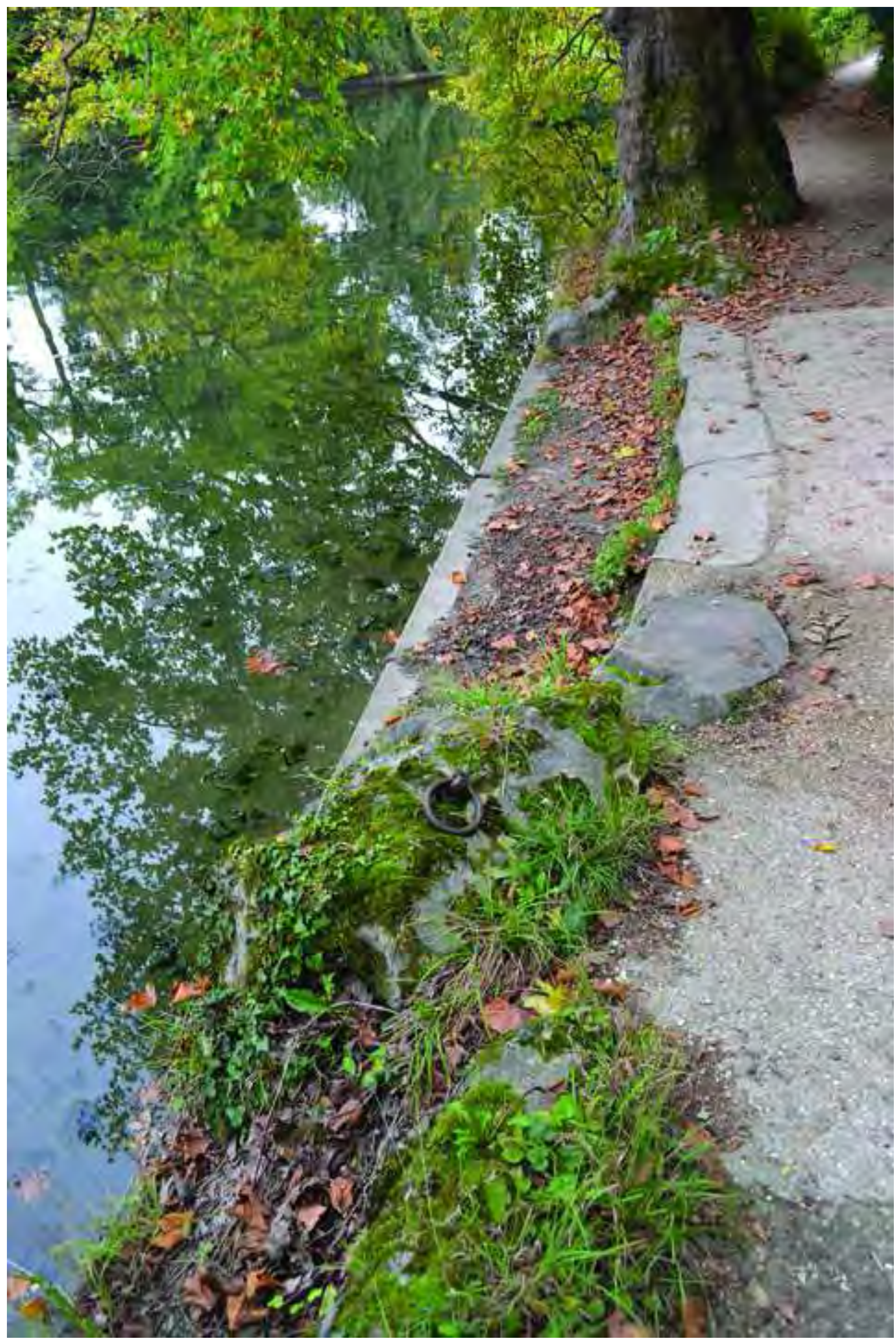




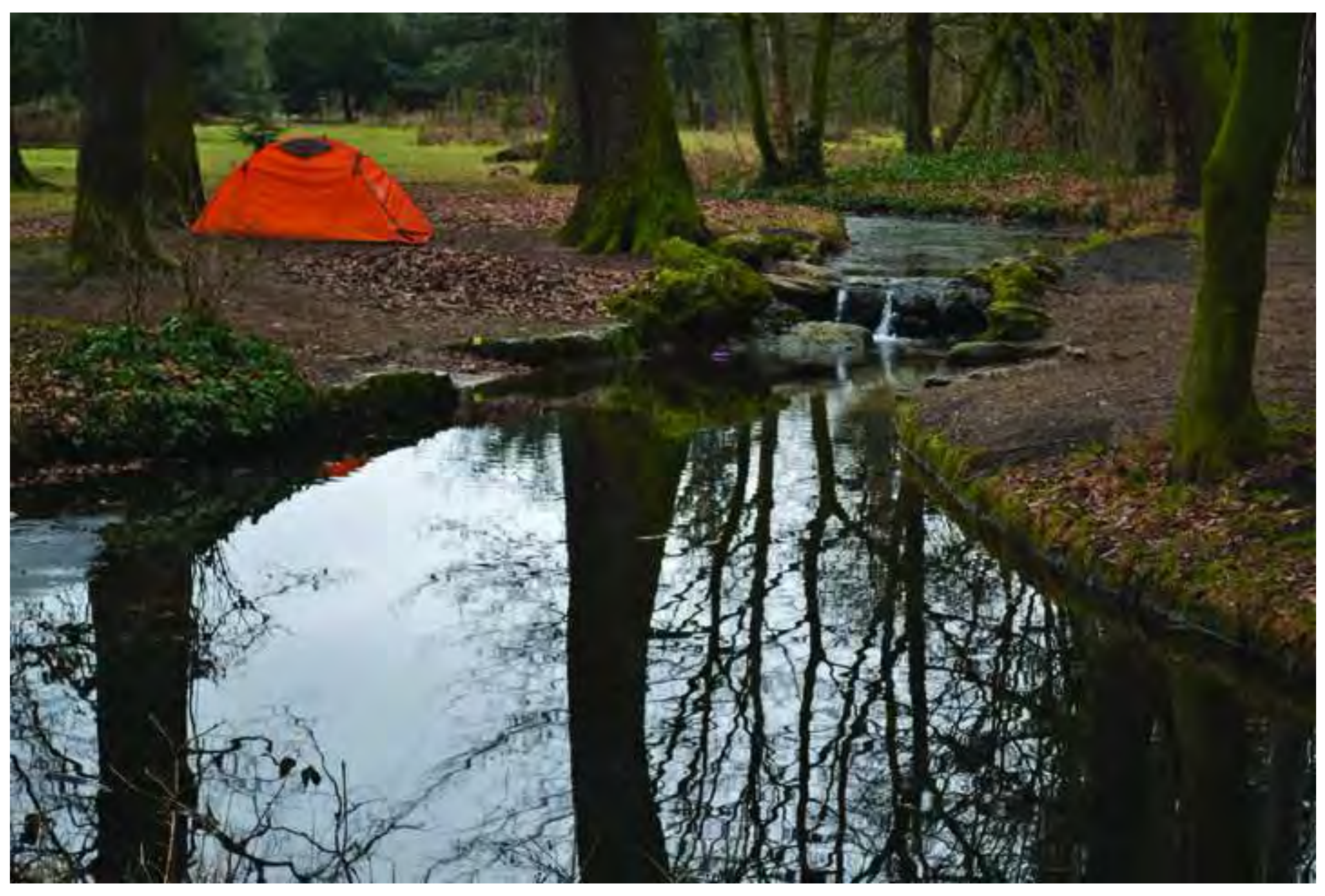




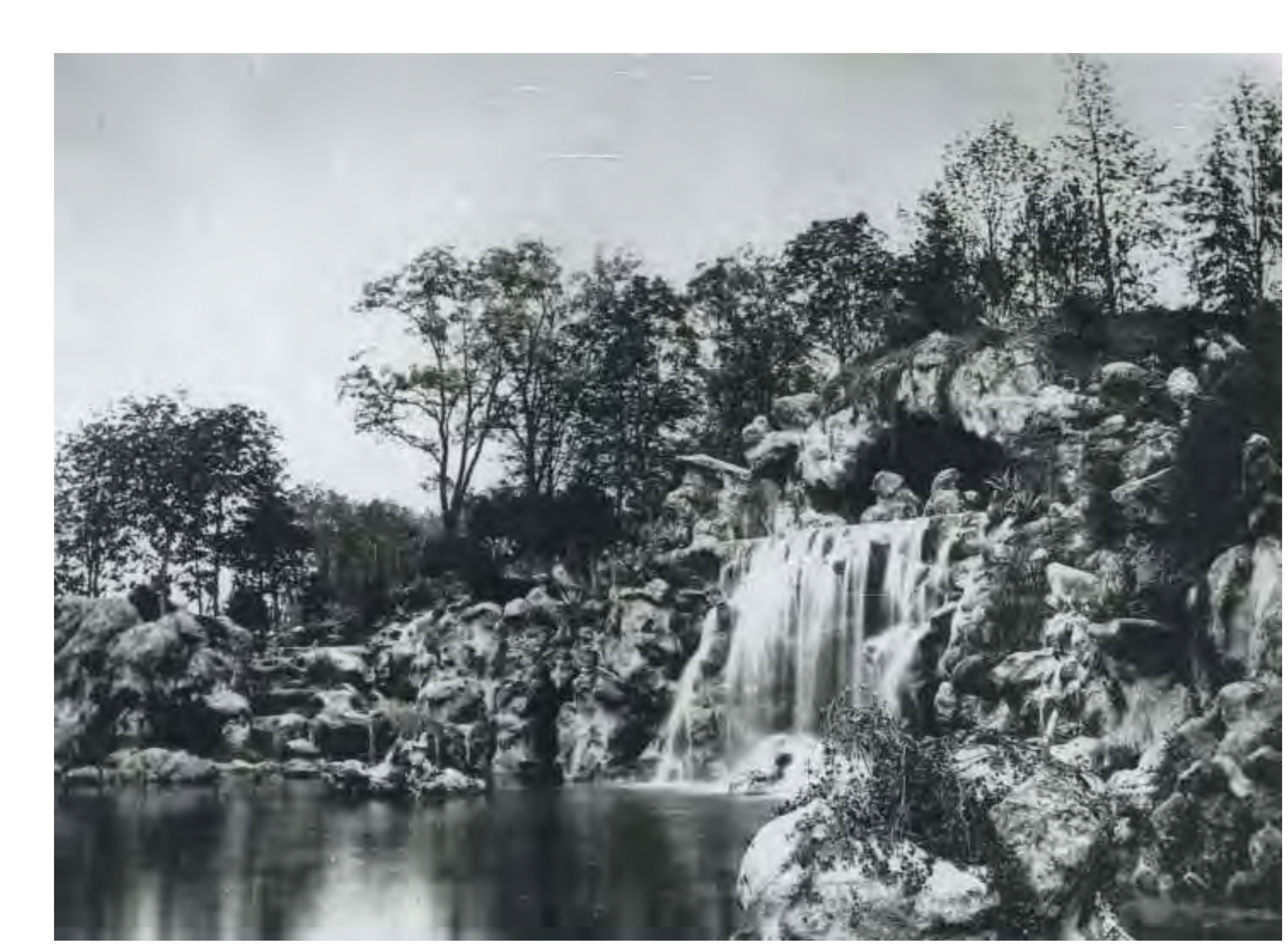

Fing is

54050 क

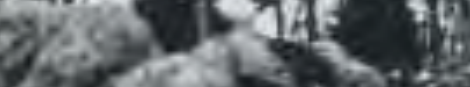

-

in 


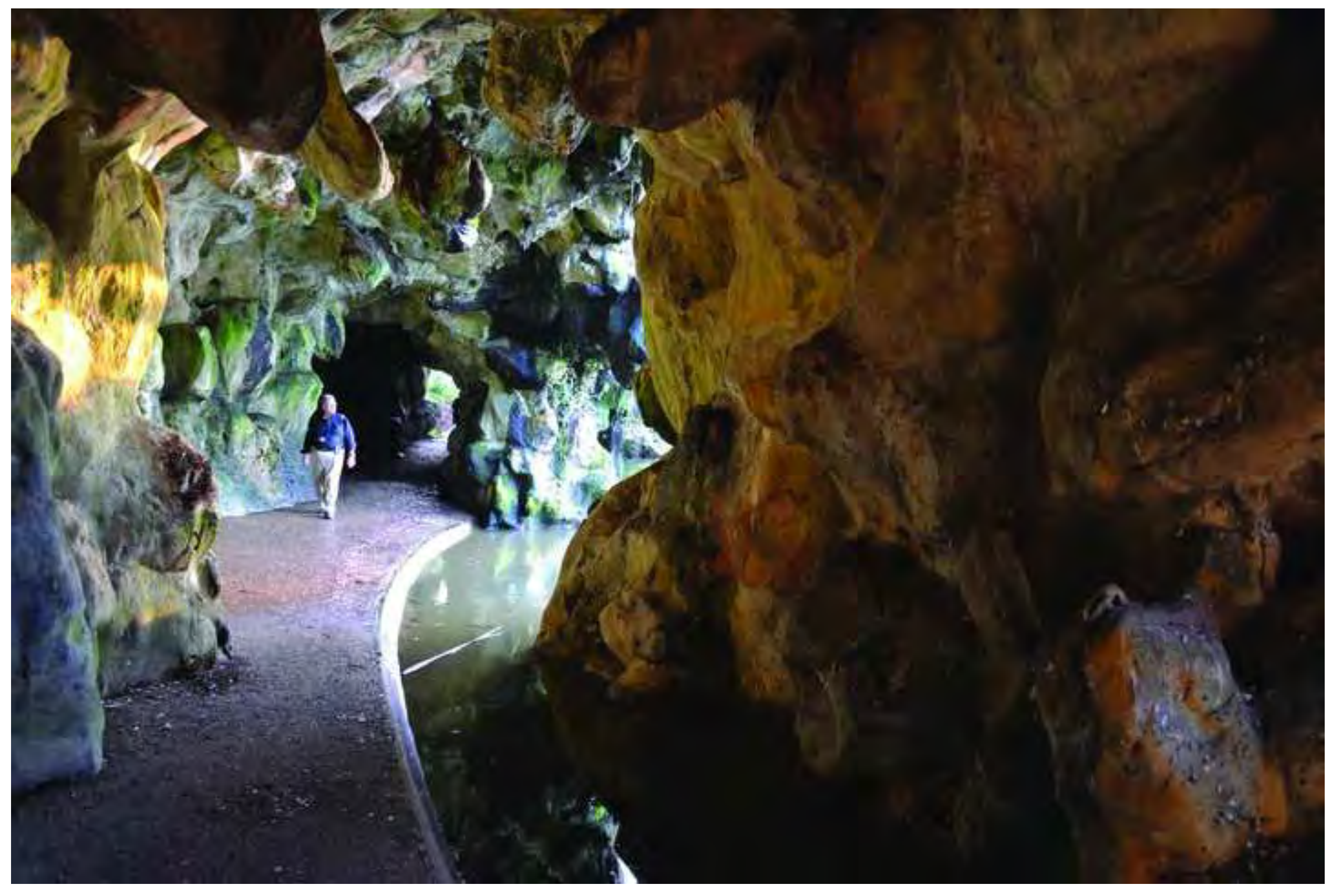




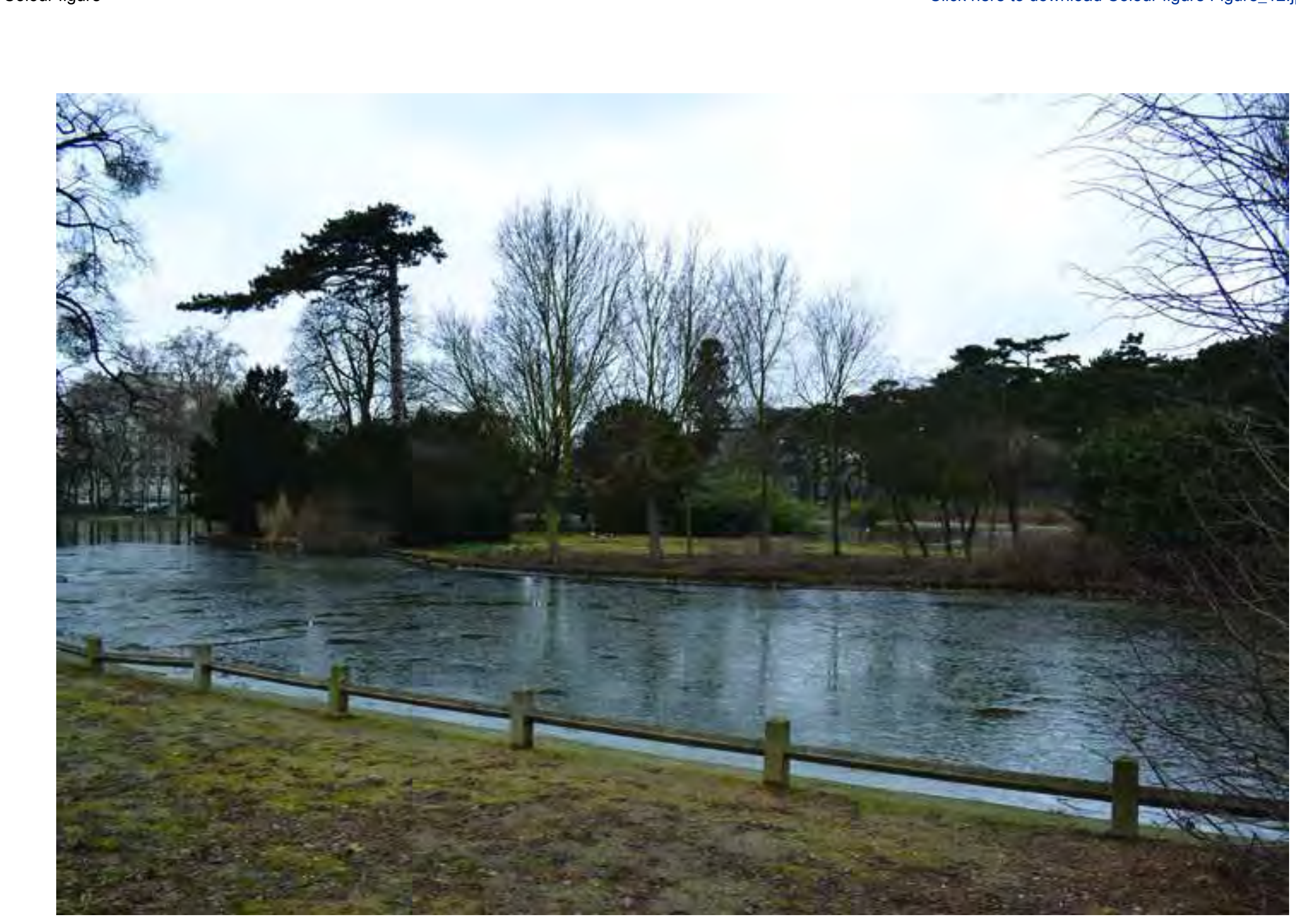




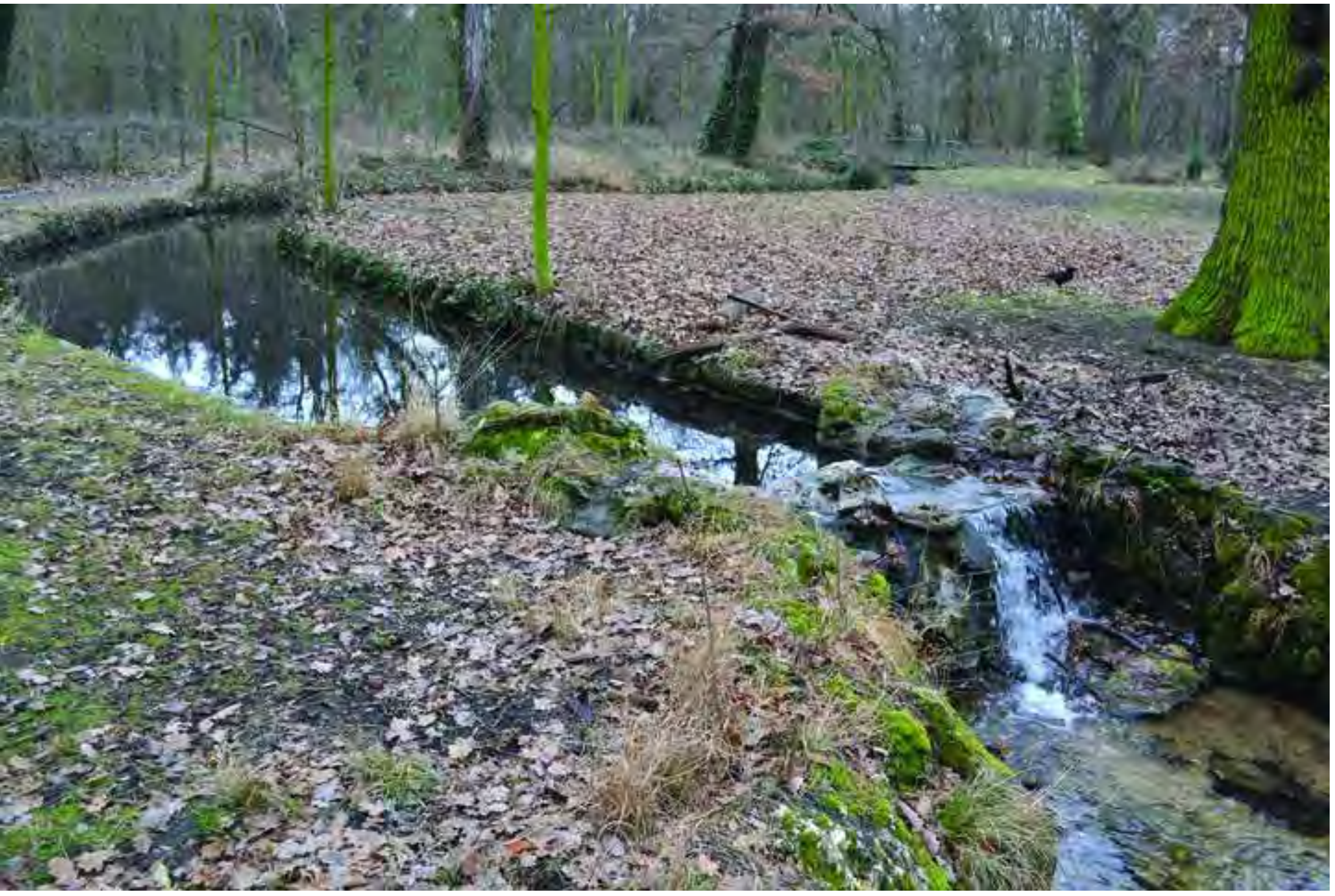

